\title{
Bandas de Hunter-Schreger: Propuesta Terminológica
}

\author{
Hunter-Schreger Bands: Terminological Propose
}

Ignacio Roa ${ }^{1,2} \&$ Nikol Ponce ${ }^{2,3}$

ROA, I. \& PONCE, N. Bandas de Hunter-Schreger: Propuesta terminológica. Int. J. Morphol., 37(4):1210-1212, 2019.

RESUMEN: Las Bandas de Hunter-Schreger (BHS), son bandas claras y oscuras, que se aprecian en el esmalte debido a la distínta curvatura de los prismas del esmalte, resultan ser ampliamente mencionadas en estudios, tanto odontológicos como antropológicos, mas no se ven reflejadas en Terminologia Histologica. El objetivo del presente trabajo fue realizar un análisis del término BHS, con el fin de proponerlo como nuevo término histológico, y así poder ser incluido en Terminologia Histologica por la Federative International Programme for Anatomical Terminology (FIPAT). Luego del análisis en textos de estudio y publicaciones científicas, proponemos en

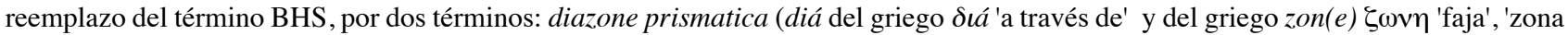
de la tierra') y parazone prismatica (pará $\pi \alpha \varrho \alpha$ gr. 'a lo largo de' y del griego zon(e) $\zeta \omega v \eta$ 'faja', 'zona de la tierra'), definiendo así términos más descriptivos y que no utilizan epónimos, tal como lo establece la Terminología Internacional. Proponer nuevos términos que estén más acorde con los señalado por la International Federation of Associations of Anatomists (IFAA) y la propia terminología, presenta grandes desafíos; un término no sólo es una palabra que hace referencia a una estructura morfológica, sino que también es una unidad del lenguaje, que une a la comunidad morfológica en un solo lenguaje. Por lo cual proponemos que el término sea incluido por la FIPAT en próximas discusiones.

PALABRAS CLAVE: Bandas de Hunter-Schreger; Esmalte; Terminologia Histologica.

\section{INTRODUCTION}

La compleja microestructura interna del esmalte, refleja la naturaleza del mecanismo detrás de su formación y las exigencias biomecánicas a las que se encuentra expuesto (Rensberger, 1997). Es así como durante la secreción de esmalte por parte de los ameloblastos, son formadas una serie de estructuras, dentro de ellas los prismas del esmalte; bastones alargados de trayecto ondulado, formados por cristales de hidroxiapaptita, que se extienden desde la unión amelodentinaria hasta la superficie (Osborne, 1973; Lynch et al., 2010) (Fig.1). Al hacer incidir luz sobre la superficie seccionada longitudinalmente del esmalte, son apreciadas bandas claras-oscuras, observadas principalmente por al trayecto irregular de los prismas del esmalte. Dichas bandas claras y oscuras; son las llamadas Bandas de HunterSchreger (BHS) (Arrieta et al., 2018) (Fig. 2).

Como ya ha sido analizado con anterioridad, son múltiples las estructuras de la Histología oral, que se encuentran excluidas de Terminologia Histologica (Roa \& Navarrete, 2018). En dichos términos aún predomina el uso de epónimos y sinónimos; siendo estas denominaciones muchas veces poco descriptivas (Roa \& Navarrete, 2018), aunque ampliamente utilizadas, como es el caso de BHS (Ramenzoni \& Line, 2006; von Koenigswald et al., 2010; Linch et al., 2010, 2011; Tseng, 2011).

El objetivo del presente estudio fue realizar un análisis del término BHS con el fin de modificarlo y proponer un nuevo término histológico a ser incluido en Terminologia Histologica por la Federative International Programme for Anatomical Terminology (FIPAT).

\section{ANÁLISIS DE LA TERMINOLOGÍA Y DISCUSIÓN}

El término BHS, describe a las bandas claro-oscuras presentes en el esmalte de un diente seccionado longitudinalmente al momento de incidir la luz en él, formadas por las secciones de los prismas, pudiendo invertirse

\footnotetext{
${ }^{1}$ Unidad de Morfología, Departamento de Ciencias Básicas Biomédicas, Facultad de Ciencias de la Salud, Universidad de Talca, Talca, Chile.

${ }^{2}$ Programa de Doctorado en Ciencias Morfológicas, Facultad de Medicina, Universidad de La Frontera, Temuco, Chile.

${ }^{3}$ Unidad de Fisiología, Departamento de Ciencias Básicas Biomédicas, Facultad de Ciencias de la Salud, Universidad de Talca, Talca, Chile. Financiamiento: IR: Beca Comisión de Estudios Universidad de Talca, Chile. RU1448; Becario CONICYT-PCHA/Doctorado Nacional/2015-21150235. NP: Becario CONICYT-PCHA/Doctorado Nacional/2019-21190655.
} 


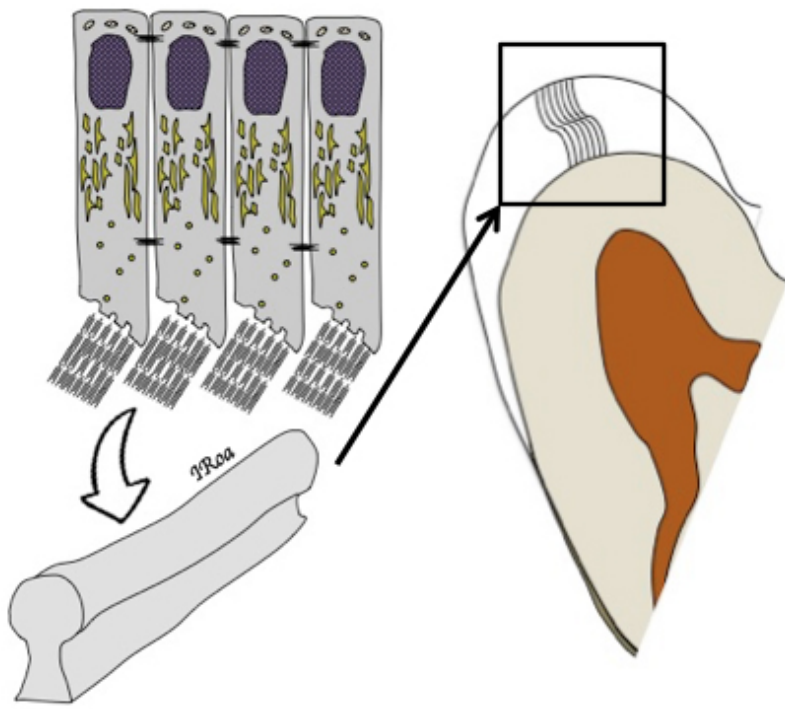

Fig.1. Proceso de secreción de esmalte por parte de los ameloblastos y formación de los prismas del esmalte. Orientación de los prismas del esmalte en forma de "S" itálica.

al cambiar la dirección de la fuente de luz (Arrieta \& Line, 2017). El nombre es en reconocimiento de los primeros investigadores acreditados con la observación de este curioso fenómeno; John Hunter, cirujano, anatomista, fisiólogo y patólogo Escocés (1728-1793) y Christian H.T. Schreger, anatomista y químico Alemán (1768-1833) (Hunter, 1778; Schreger, 1800; Hoffman-Axthelm, 1981; Homma, 1990).

Luego de analizar el texto "Terminologia Histologica: International terms for human cytology and histology" (FICAT, 2008), en su Encabezado: Systema digestorium (H3.04.00.0.00001), Encabezado Os (H3.04.01.0.00001), Encabezado: Dens (H3.04.01.0.02001), Término: Enamelum (H3.04.01.0.02011), no existe alusión a dicho término, tal

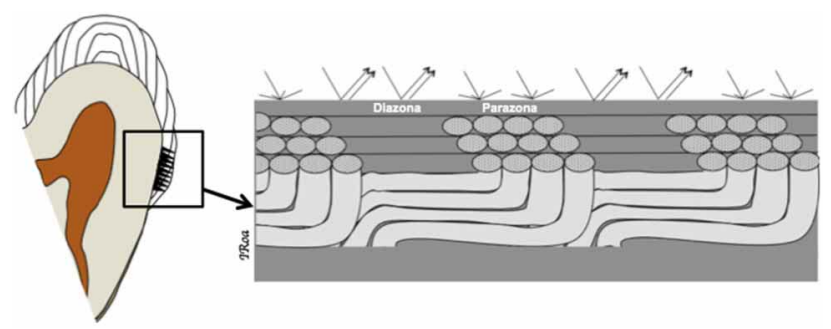

Fig. 2. Esquema de la formación de las BHS; el patrón de luz reflejada de las secciones de esmalte es un fenómeno de superficie. Las secciones transversales de los prismas intersecados dispersan la luz y aparecen oscuras mientras que los prismas expuestos más o menos paralelos a su eje longitudinal reflejan la luz (modificado de von Koenigswald \& Rose, 2005). como se refleja en la Tabla I, donde se evidencia la inexistencia de términos tales como Periquematíe (Roa \& del Sol, 2017), esmalte nodoso y BHS. El término BHS es ampliamente mencionado en diversos estudios, tanto odontológicos (Linch et al., 2010; 2011), forenses (Ramenzoni \& Line, 2006), peleoecológicos (Loch et al., 2016) como antropológicos y arqueológicos (von Koenigswald et al., 2010; Tseng, 2011). Las BHS son estructuras formadas por la distinta curvatura de los prismas del esmalte, luego de realizar un corte longitudinal del diente (Fig. 2.).

Ante la inexistencia del término y la basta utilización del término BHS, proponemos sean empleados los siguientes:

\section{Diazone prismatica:}

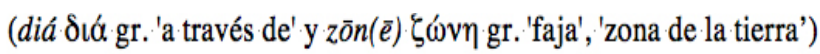
Parazone prismatica:

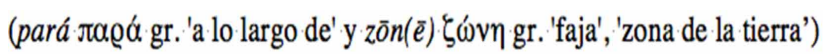

Ambos términos, diazone y parazone, son utilizados en literatura científica (Osborn, 1990; Hanaizumi et al., 2010), para referirse a bandas oscuras y claras; más éstos no reflejan ubicación, por lo cual se ha agregado el término prismatica con el fin de indicar ubicación. Definiendo así términos más descriptivos y que no utilizan epónimos, tal como lo establece la Terminología Internacional (Roa et al., 2016).

Tabla I. Términos histológicos del capítulo Esmalte, encontrados en Terminologia Histologica: International terms for human cytology and histology, 2008.

\begin{tabular}{ll}
\hline \multicolumn{1}{c}{ Código } & \multicolumn{1}{c}{ Término Latino } \\
\hline H3.04.00.0.00001 & Systema digestorium \\
H3.04.01.0.00001 & Os \\
H3.04.01.0.00002 & Cavitas oris \\
H3.04.01.0.02001 & Dens \\
H3.04.01.0.02011 & Enamelum \\
H3.04.01.0.02012 & Enameloblastus Ameloblastus \\
H3.04.01.0.02013 & Prisma enameli \\
H3.04.01.0.02014 & Membrana prismatica \\
H3.04.01.0.02015 & Stria transversa obscura \\
H3.04.01.0.02016 & Crystallum hydroxyapatiti enameli \\
H3.04.01.0.02017 & Processus enameloblasti \\
H3.04.01.0.02018 & Cuticula dentis \\
H3.04.01.0.02019 & Lamella enamelea \\
H3.04.01.0.02020 & Fusus enameli \\
H3.04.01.0.02021 & Fasciculus enemali \\
H3.04.01.0.02022 & Junctio dentinoenameli \\
H3.04.01.0.02023 & Linea incrementalis enamelea \\
H3.04.01.0.02024 & Linea neonatalis \\
\hline &
\end{tabular}


La inexistencia del término BHS en Terminologia Histologica, ha sido reportado previamente por Roa \& Navarrete (2018), sin lugar a duda la Histología oral, es un punto a mejorar, donde son múltiples las estructuras obviadas a pesar de ser ampliamente utilizadas, no solo en el ámbito odontológico sino en antropología y arqueología (von Koenigswald et al., 2010; Tseng, 2011). Estructuras relevantes al momento de evaluar patrones de evolución, alimentación, y adaptación. El estudio del patrón de BHS, se considera escasamente explorado y con potencial de análisis (Arrieta \& Line, 2017) en las disciplinas anteriormente mencionadas.

Si bien la utilización de epónimos es una práctica aún utilizada en la actualidad (Roa et al., 2016), es deber de los morfólogos resguardar el correcto uso de la Terminología, y de no existir términos que describan estructuras existentes, proponerlos, con el fin de ser incorporados al listado oficial de la Federación Internacional de Asociaciones de Anatomía (IFAA); ya que un término no sólo es una palabra que hace referencia a una estructura morfológica, es además una unidad del lenguaje, que une a la comunidad morfológica en una sola manera de comunicarse. Por su importancia no solo morfológica, proponemos que el término sea incluido por la FIPAT en próximas discusiones.

ROA, I. \& PONCE, N. Hunter-Schreger bands: terminological propose. Int. J. Morphol., 37(4):1210-1212, 2019.

SUMMARY: Hunter-Schreger Bands (HSB), are light and dark bands, which can be seen in the enamel due to the different curvature of the enamel prisms, they are widely mentioned in studies, both dental and anthropological, but are not reflected in Terminologia Histologica. The aim of the present work was to carry out an analysis of the HSB term, in order to propose it as a new histological term, and thus be able to be included in Terminologia Histologica by the Federative International Program for Anatomical Terminology (FIPAT). After the analysis in study texts and scientific publications, we propose in replacement of the term HSB, for two terms: diazone prismatica (diá of Greek $\delta \iota a ́$ 'through' and of Greek zon(e) $\zeta \omega v \eta$ 'strip', 'zone of the earth') and parazone prismatica (pará $\pi \alpha \varrho \alpha ́$ gr. 'along' and from the Greek zon(e) $\zeta \omega v \eta$ 'strip', 'zone of the earth'), thus defining the most descriptive and noneponymous terms, as the International Terminology says. Propose new terms that are more in agreement with those indicated by the International Federation of Associations of Anatomists (IFAA) and the own terminology, presents great answers; A term is not only a word that refers to a morphological structure, but also a unit of language, which unites the morphological community in a single language. So we propose that the term sea included by the FIPAT in the next discussions.

KEY WORDS: Hunter-Schreger bands; Enamel; Terminologia Histologica.

\section{REFERENCIAS BIBLIOGRÁFICAS}

Arrieta, Z. L. \& Line, S. R.P. Optimizing the analysis of dental enamel microstructure in intact teeth. Microsc. Res. Tech., 80(7):693-6, 2017.

Arrieta, Z. L.; Fogalli, G. B. \& Line, S. R. P. Digital enhancement of dental enamel microstructure images from intact teeth.Microsc.Res.Tech., 81(9):1036-41, 2018.

Federative International Comittee on Anatomical Terminology (FICAT). Terminologia Histologica, International Terms for Human Cytology and Histology. Philadelphia, Wolters Kluwer/Lippincott Williams \& Wilkins, 2008.

Hanaizumi, Y.; Yokota, R.; Domon, T.; Wakita, M. \& Kozowa, Y. The initial process of enamel prism arrangement and its relation to the Hunter-Schreger in dog teeth. Arch. Histol. Cytol., 73(1):23-36, 2010.

Hoffman-Axthelm, W. History of Dentistry. Chicago, Quintessence Publishing, 1981.

Homma, K. Historical studies on the striae of Hunter-Schreger. Dent. Jpn. (Tokyo), 27(1):141-5, 1990 .

Hunter, J. The Natural History of the Human Teeth: Explaining their Structure, Use, Formation, Growth, and Disease including a Practical Treatise on the Diseases of the Teeth: Intended as a Supplement to the Natural History of these Part. $2^{\text {nd }}$ ed. Birmingham, Facsimile Reproduction published in 1980 by The Classics of Medicine Library, 1778.

Loch, C.; Boessenecker, R. W.; Churchill M. \& Kieser, J. Enamel ultrastructure of fossil and modern pinnipeds: evaluating hypotheses of feeding adaptations in the extinct walrus Pelagiarctos. Naturwissenschaften, 103(5-6):44, 2016.

Lynch, C. D.; O’Sullivan, V. R. Dockery, P.; McGillycuddy, C. T.; Rees, J. S. \& Sloan, A. J. Hunter-Schreger Band patterns and their implications for clinical dentistry. J. Oral Rehabil., 38(5):359-65, 2011

Lynch, C. D.; O’Sullivan, V. R.; Dockery, P.; McGillycuddy, C. T. \& Sloan. A. J. Hunter-Schreger Band patterns in human tooth enamel.J.Anat., 217(2):106-15, 2010.

Navarrete, J. \& Roa, I. Uso de Terminologia Histologica en textos de histología oral: capítulo esmalte. Int. J. Morphol., 36(3):1022-7, 2018.

Osborn, J.W.A3-dimensional model to describe the relation between prism directions, parazones and diazones, and the Hunter-Schreger bands in human tooth enamel. Arch. Oral Biol., 35(11):869-78, 1990.

Osborn, J. W. Variations in Structure and Development of Enamel. In: Melchior, A H. \& Zarb, G. A (Eds.). Oral Sciences Reviews 3: Dental Enamel. Copenhagen, Munksgaard, 1973.

Ramenzoni, L. L. \& Line, S. R. Automated biometrics-based personal identification of the Hunter-Schreger bands of dental enamel.Proc.Biol.Sci., 273(1590):1155$8,2006$.

Rensberger, J. M. Mechanical Adaptation in Enamel. In: Koenigswald, W. V.\& Sander, P. M. (Eds.). Tooth Enamel Microstructure. Rotterdam, Balkema, 1997.

Roa, I. \& del Sol, M. Perikymata: A non-existent term. A scientific literatura invention? Terminology analysis and proposal. Int. J. Morphol., 35(4):1230-2, 2017.

Roa, I.; Vásquez, B. \& Contreras, M. Eponyms persistence in Terminologia Histologica. Int. J. Morphol., 34(4):1245-52, 2016.

Schreger, D. Beitrag zur Geschichte der Zähne. Beitr Zergliederungskunst, 1:1-7, 1800.

Tseng, Z. J. Variation and implications of intra-dentition Hunter-Schreger band pattern in fossil hyaenids and canids (Carnivora, Mammalia). J. Vert. Paleontol., 31(5):1163-7, 2011.

von Koenigswald, W. \& Rose, K. D. The enamel microstructure of the early eocene Pantodont Coryphodonand the nature of the zigzag enamel. J. Mammal. Evol., 12(3):419-32, 2005.

von Koenigswald, W.; Holbrook, L. T. \& Rose, K. D. Diversity and evolution of Hunter-Schreger Band configuration in tooth enamel of perissodactyl mammals. Acta Palaeontol. Pol., 56(1):11-32, 2011.

Dirección para correspondencia:

Dr. Ignacio Roa Henríquez

Unidad de Morfología

Departamento de Ciencias Básicas Biomédicas

Facultad de Ciencias de la Salud

Universidad de Talca Av. Lircay s/n

Talca - CHILE

Recibido : 13-12-2018

E-mail: iroa@utalca.cl
Aceptado: 08-04-2019 